\title{
CAMA
}

Centre for Applied Macroeconomic Analysis

\section{Challenges of Fiscal Policy in Emerging and Developing Economies}

\section{CAMA Working Paper 34/2016 June 2016}

\section{Raju Huidrom}

World Bank, Development Prospects Group

\section{Ayhan Kose}

World Bank, Development Prospects Group

Brookings Institution

CEPR and

Centre for Applied Macroeconomic Analysis, ANU

\section{Franziska L. Ohnsorge}

World Bank, Development Prospects Group

\begin{abstract}
This paper presents a systematic analysis of the availability and use of fiscal space in emerging and developing economies. These economies built fiscal space in the run-up to the Great Recession of 2008-09, which was then used for stimulus. This reflects a more general trend over the past three decades, where availability of fiscal space has been associated with increasingly countercyclical (or less procyclical) fiscal policy. However, fiscal space has shrunk since the Great Recession and has not returned to pre-crisis levels. Emerging and developing economies face downside risks to growth and prospects of rising financing costs. In the event that these cause a sharp cyclical slowdown, policymakers may need to employ fiscal policy as a possible tool for stimulus. An important prerequisite for fiscal policy to be effective is that these economies have the necessary fiscal space to employ countercyclical policies. Over the medium-term, credible and well-designed institutional arrangements, such as fiscal rules, stabilization funds, and medium-term expenditure frameworks, can help build fiscal space and strengthen policy outcomes.
\end{abstract}




\section{Keywords}

Fiscal space, fiscal policy, developing economies, growth slowdown, fiscal rules, stabilization funds, expenditure frameworks

\section{JEL Classification}

$\mathrm{E} 62, \mathrm{H} 50, \mathrm{H} 60$

\section{Address for correspondence:}

(E) cama.admin@anu.edu.au

\section{ISSN 2206-0332}

The Centre for Applied Macroeconomic Analysis in the Crawford School of Public Policy has been established to build strong links between professional macroeconomists. It provides a forum for quality macroeconomic research and discussion of policy issues between academia, government and the private sector.

The Crawford School of Public Policy is the Australian National University's public policy school, serving and influencing Australia, Asia and the Pacific through advanced policy research, graduate and executive education, and policy impact. 


\title{
Challenges of Fiscal Policy in Emerging and Developing Economies
}

\author{
Raju Huidrom, M. Ayhan Kose, and Franziska L. Ohnsorge*
}

June 2016

\begin{abstract}
This paper presents a systematic analysis of the availability and use of fiscal space in emerging and developing economies. These economies built fiscal space in the run-up to the Great Recession of 2008-09, which was then used for stimulus. This reflects a more general trend over the past three decades, where availability of fiscal space has been associated with increasingly countercyclical (or less procyclical) fiscal policy. However, fiscal space has shrunk since the Great Recession and has not returned to pre-crisis levels. Emerging and developing economies face downside risks to growth and prospects of rising financing costs. In the event that these cause a sharp cyclical slowdown, policymakers may need to employ fiscal policy as a possible tool for stimulus. An important prerequisite for fiscal policy to be effective is that these economies have the necessary fiscal space to employ countercyclical policies. Over the mediumterm, credible and well-designed institutional arrangements, such as fiscal rules, stabilization funds, and medium-term expenditure frameworks, can help build fiscal space and strengthen policy outcomes.
\end{abstract}

Key Words: Fiscal space, fiscal policy, developing economies, growth slowdown, fiscal rules, stabilization funds, expenditure frameworks

JEL Codes: E62, H50, H60

*Huidrom: World Bank, Development Prospects Group; rhuidrom@worldbank.org. Kose: World Bank, Development Prospects Group; Brookings Institution; CAMA; CEPR; akose@worldbank.org. Ohnsorge: World Bank, Development Prospects Group; fohnsorge@worldbank.org. We thank S. Amer Ahmed, Jamus J. Lim, Sergio Kurlat, and Israel Osorio-Rodarte for providing valuable contributions. Earlier drafts benefited from comments by Raphael Espinoza, Ugo Panizza, Luis Serven, Carlos Vegh, and Hakan Yilmazkuday. We thank Naotaka Sugawara for excellent research assistance. Ethan Ilzetski kindly shared data. The findings, interpretations, and conclusions expressed in this article are entirely those of the authors. They do not necessarily represent the views of the World Bank, its Executive Directors, or the countries they represent. 


\section{Introduction}

An important prerequisite for fiscal policy to be useful is that governments need to have the necessary fiscal space to implement countercyclical measures. Another prerequisite is that countercyclical fiscal policy has to be actually effective in raising the level of economic activity. ${ }^{1}$ This paper presents a systematic analysis of the availability and use of fiscal space in developing economies. Specifically, we address the following three questions. First, how has fiscal space evolved over time? Second, have developing economies "graduated" from the procyclicality of fiscal policy during the 1980s? Third, drawing lessons from country experiences, what institutional arrangements might strengthen fiscal space and policy outcomes?

Growth in many emerging and developing economies has slowed in recent years and financing costs they face are expected to rise. ${ }^{2}$ Tightening of global financial conditions and bouts of financial market volatility might cause sharper slowdowns or reversals of capital inflows. Since the risk to capital flows can constrain monetary policy in these economies, the option of fiscal policy as a countercyclical tool becomes particularly important. But, how effective will fiscal policy be in supporting activity in the event of a downturn?

We report three main findings. First, during the 2000s, in the run-up to the Great Recession of 2008-09, developing economies, in particular Emerging Markets (EM) and Frontier Markets (FM) economies, built fiscal space by reducing debt and closing deficits (Figure 1). To support activity during the Great Recession, this space was used for fiscal stimulus. Deficits rose and have remained elevated as EM and FM have taken advantage of historically low interest rates. Second, fiscal policy in EM and FM has become countercyclical (or less procyclical) since the 1980s, as most clearly demonstrated during the Great Recession. Third, well-designed and credible institutional frameworks, such as fiscal rules, stabilization funds, and medium- term expenditure frameworks, can help build fiscal space and strengthen policy outcomes.

This paper makes three distinct contributions to the literature. First, we track the evolution of fiscal space measures using a wide range of indicators for a large set of emerging and developing economies. In particular, using an event study we systematically analyze the availability and use of fiscal space during economic contractions, comparing and contrasting the experience during the Great Recessions and previous contraction episodes. Second, we corroborate and extend the "graduation" literature - fiscal policy in developing economies has become less procyclical or countercyclical (Frankel, Végh, and Vuletin 2013) - in several dimensions. We highlight how graduation is tied to the level of fiscal space: economies that have fiscal space tend to deploy countercyclical policies. From a methodological standpoint, graduation is established much more clearly in this paper by using a structural vector autoregression model that allows us to infer the causal response of fiscal policy to macroeconomic conditions. Correlation analyses often used in previous studies on graduation merely refer to the association between fiscal policy and macroeconomic conditions thereby blurring any causal inference - a point emphasized in Ilzetski and Végh (2008). We extend the time series coverage used in previous studies and analyze the cyclicality of fiscal policy in developing economies during and after the Great Recession. Third, we present a comprehensive review of institutional arrangements that help strengthen fiscal space and policy outcomes, drawing lessons from country experiences.

\footnotetext{
${ }^{1}$ The effectiveness of fiscal policy is related to the size of the fiscal multiplier - the change in activity for a dollar increase in government spending. See World Bank (2015) and Huidrom et al. (2016).

${ }^{2}$ See Didier et al. (2015) for a discussion on the growth slowdown in emerging and developing economies. Arteta et al. (2015) discusses the implications of the upcoming tightening cycle of the U.S. Federal Reserve.
} 
The rest of the paper is organized as follows. Section 2 describes the methodology. We outline the conceptual framework for defining and measuring fiscal space and policy. We also describe the event study and the econometric model used to analyze the cyclicality of fiscal policy. Section 3 describes the databases. We present the empirical results in Section 4. In this section, we show the evolution of fiscal space and fiscal policy in developing economies, in particular EM and FM. In Section 5, we discuss the institutional arrangements designed to implement sound fiscal policy. Section 6 concludes.

\section{Methodology}

We begin by laying out a conceptual framework to define fiscal space. We then describe the various measures of fiscal space and policy used in this paper. We systematically analyze these measures, cutting the data across countries and across time. Specifically, we use an event study to analyze fiscal space and policy during economic contraction events. Finally, we discuss the cyclicality of fiscal policy: how fiscal policy in conducted over the business cycle.

\subsection{Measures of Fiscal Space}

A range of definitions for fiscal space is used in the literature. We follow the definition of Ley (2009) and define fiscal space as the "availability of budgetary resources for a specific purpose... without jeopardizing the sustainability of the government's financial position or the sustainability of the economy." This broad definition allows fiscal space to be considered along multiple dimensions. ${ }^{3}$ The first is fiscal solvency risk. The second delineates balance sheet vulnerabilities, such as maturity profile and nonresident shares of government debt, which could generate rollover or liquidity risk for sovereign debt. The third dimension involves factors that could stress private sector balance sheets, and eventually lead to the buildup of contingent fiscal liabilities - such as the ratio of external debtto-GDP or to foreign reserves, the share of short-term debt in external debt, and domestic credit to the private sector relative to gross domestic product (GDP).

In line with the literature, we track fiscal space mainly in terms of fiscal solvency. The other dimensions of fiscal space are covered in a companion paper (Kose, Kurlat, and Ohnsorge 2016). Fiscal solvency risk is measured in three alternative ways to capture different elements: first, the government debt-to-GDP ratio (a stock measure of current debt sustainability); second, the fiscal balance-to-GDP ratio (a flow measure of debt accumulation, indicating future debt sustainability, and also one of the measures of rollover risk); and third, the sustainability gap. The sustainability gap is defined as the difference between the actual primary balance and the debt-stabilizing primary balance, which depends on the target debt-to-GDP ratio to be achieved in the long run, the interest rate, and growth. ${ }^{4}$ This last measure recognizes that debt sustainability depends on output growth and interest rates, as well as on outstanding debt and deficits. In addition to these measures of

\footnotetext{
${ }^{3}$ This multidimensional definition helps address the ambiguity of how fiscal space is defined in much of the literature (Perotti 2007). Heller (2005) describes fiscal space more broadly as the budgetary room that allows a government to provide financial resources for a specific activity without affecting its financial sustainability while Ostry et al. (2010) defines fiscal space specifically as the difference between the current public debt and their estimate of the debt limit implied by the economy's history of fiscal adjustments.

${ }^{4}$ The debt stabilizing primary balance is defined as the primary balance that allows debt to converge to a target debt-to-GDP ratio. This is assumed to be the median stock of public debt as a share of a GDP for a given country grouping. The primary balance is the fiscal balance net of interest expense. Throughout this paper, government debt refers to gross general government debt unless otherwise specified.
} 
fiscal solvency risk, we briefly discuss some aspects of balance-sheet vulnerabilities and privatesector debt.

Government debt and fiscal balances in percent of GDP are readily available. We calculate fiscal sustainability gaps following Ley (2009) who captures the pressures on fiscal sustainability that emerge from large fiscal balances accumulating over time to unsustainable debt stocks, even when initial debt stocks are modest. The overall balance sustainability gap, ogap, is given by:

$$
\text { ogap }=b-\left(\frac{-\gamma}{1+\gamma}\right) d^{*}
$$

where $\gamma$ represents the nominal GDP growth rate, $b$ the overall fiscal balance (in percent of GDP), and the last term the overall fiscal balance that stabilizes the stock of debt (in percent of GDP) at $d^{*}$. The stock of debt $d^{*}$ is the target debt-to-GDP ratio that is taken to the median in a given country group. ${ }^{5}$ The primary balance sustainability gap, pgap, is the difference between the primary balance and the debt-stabilizing primary balance:

$$
\text { pgap }=p-\left(\frac{i-\gamma}{1+\gamma}\right) d^{*}=p-\left(\frac{r-g}{1+g}\right) d^{*}
$$

where $p$ is the primary balance (in percent of GDP), $i$ is the nominal long-term interest rate ,$\gamma$ is the nominal GDP growth, $r$ is the real interest rate (defined as the nominal interest rate deflated by the U.S. GDP deflator), $g$ is the real growth rate, and $d^{*}$ is the target stock of debt. ${ }^{6}$ The primary balance sustainability gap is calculated using (i) average growth and interest rates over the entire sample period, and (ii) current growth and interest rates.

In addition to government finances, private-sector debt has the potential to impact fiscal sustainability if governments respond to a shock by assuming some of the private sector liabilities. The costs associated with such interventions rise with the overall size of the private sector obligations and maturity or currency mismatches. We primarily use data on private sector credit to assess private sector debt vulnerabilities. In particular, we use the share of domestic credit to the private sector as a share of GDP which is available through the World Development Indicators (WDI) database. It refers to the sum of financial corporations' claims on the non-financial private sector (and, for some countries, on public enterprises too).

\subsection{Measures of Fiscal Policy}

There are several measures of the stance of fiscal policy. This paper employs two that are commonly used in the literature: the structural balance and government consumption. The structural balance strips from the overall balance the rise and fall of revenues (such as the cycle-induced component of income taxes) and expenditures (especially social benefits) that can be attributed to the

\footnotetext{
${ }^{5}$ During 1980-2014 (the sample period used in this paper), the median debt levels are 58 percent of GDP for AM; 43 percent of GDP for the combined EM, FM, and OD; and 56 percent for LIC. If only the post-2001 sample is considered the median for LIC would be lower. As such, the sustainability gap estimated in this chapter is more optimistic for LIC than would be suggested if the post-2001 median debt were considered.

${ }^{6}$ The nominal long-term interest rate is proxied by the 10-year government bond yield for a group of 42 economies that have data available (through Bloomberg) over a reasonably long period. For another group of 43 countries, the rate is estimated as the sum of U.S. dollar LIBOR plus the predicted spreads from a fixed-effect OLS regression of J. P. Morgan's EMBI on the Institutional Investor Rating.
} 
business cycle. In this paper, the structural balance is defined as the difference between cyclicallyadjusted revenues (assuming an output-gap elasticity of one for revenues) and cyclically-adjusted expenditures (assuming an elasticity close to zero). ${ }^{7}$ The structural balance, sbal, is given by:

$$
\text { sbal }=\text { revenues }(1+\text { ygap })^{-1}-\text { expenditures }(1+\text { ygap })^{0.1},
$$

where ygap denotes the output gap.

The other measure, government consumption expenditures, which are mainly government wages and outlays on goods and services, provides a narrower definition of the fiscal policy stance, but one that is more readily comparable across economies and not subject to the uncertainty surrounding the accuracy of cyclical adjustments, for example the uncertainty about the cyclical income elasticity of tax revenues or the size of the output gap.

\subsection{Identifying Contraction Events}

We employ an event study analysis to understand how developing economies use fiscal space and policy during economic downturns. We define an economic contraction event as follows: an economy is considered here to have experienced a contraction event if its growth in a given year fulfills two conditions. $^{8}$ The first is that the growth is negative (i.e., a contraction), and the second is that the growth is more than one standard deviation below the average that the country experienced in the 1990-2013 period. The year of the event, as defined, is then ' $t=0$.' If there are two or more contractionary episodes within a five-year period, the year with the greatest growth contraction is taken as ' $t=0$.' This is a variation of the censoring rule applied by IMF (2012a) in its application of the Harding and Pagan (2002) quarterly business cycle dating methodology to annual data. If key fiscal space data, such as gross government debt, are not available in the database for the country in the event year, then the event is dropped. This approach identifies 101 contraction events, 50 in the pre-2008 period and 51 in 2008-09 for the full sample of all countries including Advanced Markets (AM), EM, and FM. Of the 51 economies that experienced a contraction during the Great Recession, 21 were EM or FM. ${ }^{9}$

Having identified these events, we then examine how fiscal space and fiscal policy in developing economies change in the run-up to, during, and immediately after a contraction episode. Two sets of comparisons are made. The first set is between economies with differing levels of fiscal space within the same contraction episode. The second set is between economies' contraction episodes during the Great Recession and during pre-2008 contraction episodes.

\footnotetext{
${ }^{7}$ The more commonly used definition of structural balance takes into account one-off, discretionary expenditures and changes in commodity and assets prices (IMF 2012; Bornhorst et al. 2011). Since the goal of the database is to provide comparable definitions for as broad a set of countries as possible, these country-specific, one-off adjustments are not taken into account.

${ }^{8}$ This definition of events considers output contractions only. The comprehensive financial crisis database of Laeven and Valencia (2013) has been considered a source for event dates. However, Laeven and Valencia (2013) focuses on financial crises, and thereby excludes episodes in many economies, such as those in Sub-Saharan Africa. Also, some of the episodes it considers do not necessarily have output contractions associated with them.

${ }^{9}$ These events, along with their associated real GDP contraction are given in Table A3. More than 80 percent of advanced markets (AM), a third of EM and FM, and less than a tenth of LIC experienced a contraction in 2008-09 in the sample of countries considered. Episodes identified as crises but not included in the event study because of data constraints are noted in Table A3 in the Appendix.
} 


\subsection{Cyclicality of Fiscal Policy}

The cyclicality of fiscal policy refers to how fiscal policy is conducted over the business cycle, i.e. how governments use fiscal policy in response to economic contractions and expansions. Due to data availability concerns, we infer the cyclicality of fiscal policy mainly in terms of government consumption and structural balances. ${ }^{10}$ Fiscal policy is countercyclical when government consumption (structural balance) increases (declines) during downturns. To evaluate the cyclical stance of fiscal policy in developing economies, we deploy two related exercises: first, a correlation analysis; and second, a vector autoregression model.

Correlation analysis. A standard practice used in the literature to infer the cyclicality of fiscal policy is in terms of the correlations between the cyclical components (i.e. growth rates) of government consumption and GDP (e.g. Frankel, Végh, and Vuletin 2013). Following this, we calculate those correlations using an unbalanced panel of annual data for 31 EM and 29 FM with a maximum coverage of 1980-2014. ${ }^{11}$ The correlations are calculated for different sub-samples: 1980-99 (pre-graduation), 2000-07 (post-graduation but before the Great Recession), and 2008-14 (during and after the Great Recession). The Great Recession provides a natural experiment to evaluate how developing economies used fiscal policy to stabilize the economy during downturns. Our analysis therefore is an important extension to previous studies that are confined to the period before the Great Recession.

Vector Autoregression. Strictly speaking, cyclicality of fiscal policy refers to a causal statement: how fiscal policy responds to macroeconomic conditions. Correlations merely reflect the association between fiscal policy and macroeconomic conditions, and cannot discriminate between fiscal policy responses to macroeconomic conditions (i.e. fiscal cyclicality) and responses of the macroeconomy to fiscal policy (i.e. fiscal multiplier). To address this, we deploy a structural vector autoregression (SVAR) model to isolate the responses of fiscal policy to exogenous shocks to the macroeconomy. Shocks to fiscal policy and economic activity are separately identified via a recursive identification scheme following Blanchard and Perroti (2002). ${ }^{12}$ The identification scheme assumes that discretionary fiscal policy takes at least a quarter to respond to macroeconomic conditions, i.e. it does not respond within the same quarter. The model is written as:

$$
\left[\begin{array}{cccc}
1 & 0 & 0 & 0 \\
\alpha_{0}^{21} & 1 & 0 & 0 \\
\alpha_{0}^{31} & \alpha_{0}^{32} & 1 & 0 \\
\alpha_{0}^{41} & \alpha_{0}^{42} & \alpha_{0}^{43} & 1
\end{array}\right]\left[\begin{array}{c}
g c_{i t} \\
g d p_{i t} \\
c a_{i t} \\
r e e r_{i t}
\end{array}\right]=\sum_{l=1}^{L}\left[\begin{array}{cccc}
\alpha_{l}^{11} & \alpha_{l}^{12} & \alpha_{l}^{13} & \alpha_{l}^{14} \\
\alpha_{l}^{21} & \alpha_{l}^{22} & \alpha_{l}^{23} & \alpha_{l}^{24} \\
\alpha_{l}^{31} & \alpha_{l}^{32} & \alpha_{l}^{33} & \alpha_{l}^{34} \\
\alpha_{l}^{41} & \alpha_{l}^{42} & \alpha_{l}^{43} & \alpha_{l}^{44}
\end{array}\right]\left[\begin{array}{c}
g c_{i t-l} \\
g d p_{i t-l} \\
c a_{i t-l} \\
r e e r_{i t-l}
\end{array}\right]+X_{i t} F+U_{i t}
$$

where $g c$ represents real government consumption; $g d p$, real gross domestic product (GDP), $c a$, current account as percent of GDP; reer, real effective exchange rates. Here, government consumption is taken to be the fiscal instrument and GDP tracks macroeconomic conditions. The real effective exchange rates and the current account are included in the model to account for open economy features that characterize most of the countries included in the sample.

\footnotetext{
${ }^{10}$ The cyclical stance of fiscal policy can also be inferred in terms of tax rates. However, such a series is not consistently available for a large set of countries.

${ }^{11}$ For the list of these EM and FM, see Table A1.

${ }^{12}$ This identification scheme is mainly used in the literature to estimate fiscal multipliers. In this paper, we are using it to infer fiscal cyclicality.
} 
Note the panel structure of the model where the variables are indexed for each country by $i$. The vector $U_{i t}$ represents uncorrelated independent, identically distributed "structural" shocks. The vector $X_{i t}$ denotes controls which are the country-specific intercepts. The parameter $L$ denotes the maximum lag length in the SVAR, set at 4 in line with Ilzetzki, Mendoza, and Végh (2013). The impact matrix, that is, the matrix of coefficients on the left-hand side of the equation, is lowertriangular. This along with the ordering of the variables in the VAR, is related to the recursive identification scheme used in the paper, which is that government consumption does not react to GDP within the quarter. This methodology requires quarterly data; and the analysis here, while resulting in a clearer sense of fiscal cyclicality, is limited to a smaller set of economies for which quarterly data is available. As in the case of the correlation analysis, the model is estimated during the three sub-samples (1980-1999, 2000-2007, and 2008-2014). The key idea here is to track how fiscal cyclicality - the response of government consumption to GDP shocks - has evolved over time. Fiscal policy is procyclical (countercyclical) when that response is positive (negative) and statistically significant.

\section{Database}

We use two broad sets of database covering a large set of economies. The first is at the annual frequency and covers measures of fiscal space and policy and other macroeconomic variables. The second is at the quarterly frequency and is mainly used for estimating the SVAR model. In this paper, economies are classified according to gross national income (GNI) per capita (as in the World Bank's official documents) as well as according to market access. Following this classification, economies are divided into Advanced Markets (AM), Emerging Markets (EM), Frontier Markets (FM), Other Developing Countries (OD), and Other Low Income Countries (LIC). This grouping captures financial market participants' perceptions of fiscal vulnerabilities, and aligns well with standard definitions used by financial market investors for index construction and portfolio allocation. EM include economies that currently are, or have been for most of their recent history, middle-income countries with a long-established record of access to international financial markets. FM include economies that are usually smaller and less developed than EM and, in the view of investors, considerably riskier (although economies undergoing extreme economic or political instability are excluded). Technically, the EM and FM lists consolidate the ones independently developed by FTSE and S\&P. The AM category follows the IMF classification. The list of economies included in each group is in Table A1 in the Appendix.

\subsection{Annual Database}

This database contains annual data for up to 196 countries with a maximum coverage from 1980 to 2016, with greater coverage starting from the 1990s. ${ }^{13}$ Much of the data are drawn from the IMF's World Economic Outlook (WEO) and International Financial Statistics (IFS) databases, and the World Bank's World Development Indicators (WDI) database. ${ }^{14}$ For a few specific data series, information is gathered from the Joint External Debt Hub (JEDH, a joint initiative by the World Bank, BIS, IMF, and the Organization for Economic Co-operation and Development), the Bank for International Settlements (BIS), and from Bloomberg.

\footnotetext{
${ }^{13}$ Fifty-seven small countries (defined as those with a population of less than a million) and dependent territories were excluded from most samples in the analytical sections. This chapter uses the term country interchangeably with economy, referring to territories for which authorities report separate statistics.

${ }^{14}$ In order to address quality and consistency concerns, most series are sourced from databases maintained by international organizations, in cooperation with national statistical agencies using harmonized methodologies.
} 
General government debt and fiscal balances are taken from the WEO. Domestic credit to the private sector is sourced from the WDI. We use the WDI for standard macroeconomic variables such as real GDP, private and government consumption. Real effective exchange rate is from the IFS and oil prices from the GEM Commodities database of the World Bank. The data sources are summarized in Table A4 in the Appendix.

\subsection{Quarterly Database}

This database covers an unbalanced panel of 15 EM and FM at the quarterly frequency with a maximum coverage from 1980Q1 to 2014Q1. ${ }^{15}$ Real government consumption and real GDP are based on the quarterly database in Ilzetzki, Mendoza, and Végh (2013) which is extended until 2014Q1 by splicing from the OECD Economic Outlook database and Haver Analytics. Real effective exchange rates are the narrow (wherever available) and the broad indices from BIS at the end of each quarter. The current account to GDP series is drawn from the WEO.

For estimating the SVAR model, some of the variables are transformed to yield stationary series. Government consumption and GDP series are in logs and detrended using a linear quadratic trend as in Ilzetzki, Mendoza, and Végh (2013). The real effective rate is transformed into quarter-toquarter growth rates. The current account-to-GDP ratio series is seasonally-adjusted using the X11 routine. All four series are detrended and demeaned on a country by country basis so as to control for country fixed effects while estimating the SVAR model.

\section{Empirical Findings}

\subsection{How Has Fiscal Space Evolved?}

Evolution of Space during the 2000s. Between 2001 and 2007, in the run-up to the Great Recession, fiscal space widened for much of the developing world, with government debt ratios falling and fiscal deficits closing (Figure 1). Three factors contributed to these changes. First, there was rapid growth, with government revenues in commodity exporting economies bolstered by high and rising prices (Figure 2). ${ }^{16}$ This coincided with a period of increasing graduation of developing economies' fiscal policy from earlier procyclicality to more recent countercyclicality. Second, debt relief initiatives, such as the Heavily Indebted Poor Countries (HIPC) Initiative and Multilateral Debt Relief Initiative (MDRI), helped to reduce debt sharply in many FM and LIC. ${ }^{17}$ As a result, most developing economies consolidated their finances in the early 2000s. Third, institutional arrangements in developing economies allowed for improvements in debt management, which also contributed to the reduction in debt-to-GDP ratios (Anderson, Silva and Valendia-Rubiano 2011; Frankel, Végh, and Vuletin 2013).

During the Great Recession, fiscal space narrowed as economies implemented fiscal stimulus. ${ }^{18}$ For example, the Republic of Korea boasted wide fiscal space in 2007, when government debt

\footnotetext{
${ }^{15}$ These are the economies with an asterisk in Table A1.

${ }^{16}$ Fiscal space among commodity exporters has narrowed in recent years largely due to the decline in commodity prices. The list of commodity exporting economies is in Table A2. The classification follows World Bank (2015).

${ }^{17} \mathrm{As}$ of 2014,35 countries have reached the HIPC completion point and are eligible for assistance under the initiative, of which six are FMFM and 22 are LIC (IMF 2014). The most recent assessment of debt relief costs by the IMF (2013) determined that $\$ 126$ billion has been committed under these initiatives to the 35 HIPC completion point countries, with another $\$ 442$ million committed to Chad (an interim HIPC country), Cambodia, and Tajikistan. The latter two countries are non-HIPC.

${ }^{18}$ See Eskesen (2009), Arbatli et al. (2010), and Fardoust, Lin, and Luo (2012) for a detailed discussion.
} 
was a third of GDP, and fiscal balance was in surplus. In response to the crisis, the government implemented two fiscal stimulus packages, amounting to 3.6 percent of GDP in 2009 and 1.2 percent of GDP in 2010. Korea's surplus has diminished since then and debt in 2014 reached almost 38 percent of GDP. Similarly, China had a fiscal surplus in 2007, and government debt that was just one-fifth of GDP. Following a stimulus package equivalent to 12.5 percent of GDP in 2008, China ran fiscal deficits from 2008 to 2010. Government debt rose to more than 50 percent of GDP by 2010. ${ }^{19}$ Both economies succeeded in preventing a contraction in real GDP, despite the sharp downturn in the global economy.

Space and Policy during Contractions. China and Korea were particularly pronounced examples of a broader pattern among EM and FM. Many implemented countercyclical fiscal policy during the Great Recession, but not all avoided GDP contractions. To analyze fiscal policy responses during the Great Recession as well as in past crises, we deploy the event study as described earlier.

During the Great Recession, EM and FM used the wider fiscal space they had accumulated during the preceding years to allow automatic stabilizers to operate and to implement larger fiscal stimulus than in earlier contractions. Structural balances, which measure the fiscal policy stance, declined sharply as economies entered severe contractions (Figure 3). During both event samples, fiscal space deteriorated following the stimulus, reflected in an increase in government debt. Government debt evolved differently across the two samples, likely as a result of different exchange rate movements and financial sector support programs. In particular, in pre-2008 contractions, sharp exchange rate depreciations raised the cost of holding foreign currency debt and contributed to steep increases in the debt ratio. Cases in point are the Asian crisis and the Russian crisis of the late 1990s. ${ }^{20}$ In comparison, during 2008-09, EM and FM currencies dropped less and rebounded to pre-crisis levels before the Great Recession was over. This partly reflected a different, more difficult, global environment - with a somewhat deeper contraction and weaker global recovery. The risks posed by exchange rate depreciation may be smaller for emerging economies now than in the past, due to deeper domestic financial markets and a policy decision to borrow in domestic currency, thus reducing "original sin". ${ }^{21}$

In addition, before 2008, some EM suffered systemic banking crises which required governments to provide heavy financial support. Though typically not fully reflected in deficits, such outlays substantially increased public debt above and beyond the increases attributable to the fiscal deficit (Laeven and Valencia 2013). As these cross-country experiences illustrate, the fiscal space implicit in low debt can shrink rapidly especially during periods of elevated financial stress (Figure 4).

\subsection{Have Developing Economies Graduated from Procyclicality?}

As mentioned earlier, two of the commonly used measures of fiscal policy stance are the structural balance and government consumption. On either measure, fiscal policy was significantly more expansionary during the Great Recession than during earlier contraction episodes. Structural

\footnotetext{
${ }^{19}$ The buildup of general government debt reflected a substantial expansion in local government off-balance sheet lending (World Bank 2013a, 2014).

${ }^{20}$ Kohler (2010) documents the differences in exchange rate depreciations between the $2008-09$ crisis and the Asian and Russian crises. Didier, Hevia, and Schmukler (2012) show that there were structural breaks in policy in EM, based on a comparison between policies in the Asian and Russian crises and the Great Recession. EM experienced smaller depreciations during the Great Recession. Moreover, EM lost substantially less reserves during the 2008-2009 crisis than during the Asian and Russian crises.

${ }^{21}$ Original sin refers to the inability of some developing countries to borrow internationally in their own currency (Eichengreen and Hausmann 1999). Hausmann and Panizza (2011) analyze the risks posed by original sin.
} 
balances widened, on average among EM and FM, by 4 percentage points of GDP during the Great Recession, whereas they tightened in earlier contractions (Figure 3).

The buildup of fiscal space during the global expansion of the early 2000s, and its use during the Great Recession suggest that fiscal policy has become less procyclical in developing economies. Estimated responses of government consumption to GDP shocks indeed show that fiscal policy has become less procyclical since the 1990s, and more countercyclical since the Great Recession (Figure 5). Our findings therefore corroborate and extend the "graduation" literature - fiscal policy in developing economies has become less procyclical or countercyclical (Frankel, Végh, and Vuletin 2013). ${ }^{22}$

While the sample is too small to compute estimates for EM and FM separately, correlations between real GDP and real government consumption also suggest a similarity between the two groups. High procyclicality between 1980 and 1999, broadly turned to acyclicality in EM in the early 2000s, and to countercyclicality after the Great Recession. This evolution of fiscal cyclicality can be attributed to several factors, including improvements in policies, institutions, and enhanced financial market access. ${ }^{23}$

The move to less procyclical fiscal policy has also been associated with greater fiscal space. Throughout the 2000s, procyclicality was less pronounced in economies with wide fiscal space (Figure 6). During the Great Recession, economies with government debt below 40 percent of GDP (implying wider fiscal space) were able to implement greater fiscal stimulus than more indebted governments (with narrower space).

Overall, the evidence presented in this section suggests that fiscal space matters for a government's ability to implement countercyclical fiscal policy. The next section explores institutional arrangements that can help strengthen fiscal space in developing economies.

\section{Institutional Arrangements: How Can Fiscal Space Be Strength- ened?}

The past procyclicality of fiscal policy in developing economies has been attributed in part to political economy pressures. This section discusses how credible and well-designed institutional mechanisms can help mitigate these pressures and support fiscal discipline. In particular, it highlights best practices for three institutional mechanisms - fiscal rules, stabilization funds, and mediumterm expenditure frameworks (MTEFs) - along with empirical evidence on the relative success of these institutions in strengthening fiscal space and supporting countercyclical fiscal policy.

Fiscal Rules. Fiscal rules impose lasting numerical constraints on budgetary aggregates - debt, overall balance, expenditures, or revenues. Rules often allow for flexibility in meeting budget targets by taking into account temporary cyclical deviations - such as a large output gap - or structural

\footnotetext{
${ }^{22}$ World Bank (2013b) offers explanations of the procyclical bias of fiscal policy in developing countries. Developing countries have generally procyclical access to capital markets, and governments must therefore make spending cuts during downturns, when they are less able or unable to borrow. During upswings, governments are often under political pressure to spend the higher revenues.

${ }^{23}$ Frankel, Végh, and Vuletin (2013) emphasize the importance of improvements in institutional quality for the changes in cyclicality. Calderon and Schmidt-Hebbel (2008) and World Bank (2013b) discuss the importance of greater credibility of fiscal policies and deepening domestic financial markets.
} 
adjustments, such as changes in the medium-term price of a key export. Fiscal rules, and in particular cyclically-adjusted or structural balance rules, have become increasingly popular in developing economies (Figure 7), especially since the Great Recession (Schaechter et al. 2012). Balanced budget rules have become common in Africa and Eastern Europe, often adopted alongside debt rules.

The adoption of rules, per se, has had mixed success in limiting procyclicality. Indeed, balanced budget rules that target headline fiscal balances can lead not only to more volatile business cycles but they also tend to be associated with more procyclical fiscal stances (Bova, Carcenac, and Guerguil 2014). In contrast, budget balance rules that target structural balances tend to be more closely associated with countercyclical fiscal stances. Many countries with budget rules have been transitioning to targeting cyclically-adjusted balance.

Other possible factors that explain the limited success of balanced budget rules to reduce procyclicality include challenges to enforcement such as the off-budget government guarantees (World Bank 2014), insufficient flexibility (Snudden 2013), and the need for greater transparency and improved measurement in the estimation of structural balances. Rules are best when simply defined and supported by surveillance arrangements, respected by the government, yet operated by a nongovernment agency (Frankel, 2011). Chile's use of a technical fiscal council and a fiscal rule that targets a fixed structural balance is a good example of a well-designed, credible, and successfully operated fiscal rule (World Bank 2015). ${ }^{24}$ Such agencies have legal guarantees for independence, highly qualified professional staff, and assured financing (Debrun and Schaechter 2014).

Stabilization Funds. Stabilization funds set aside receipts from significant natural resource revenues such as oil and natural gas. Funds saved during favorable times are released to cushion potential revenue shortfalls and to mitigate negative shocks to government expenditure. Stabilization funds were first set up in Kuwait in 1953, and were adopted widely in the 2000s, when high international oil prices - along with the discovery of oil in a number of economies - facilitated their establishment (Figure 8). Many stabilization funds are integrated with the budget, with clear rules to guide the accumulation and withdrawal of fund resources (Bagnall and Truman 2013). Since stabilization funds separate government expenditure from fluctuations in the availability of revenues, they can be important institutional mechanisms for improving fiscal space, while mitigating fiscal procyclicality. Although the empirical evidence is somewhat mixed, a number of studies find that stabilization funds can help improve fiscal discipline (Fasano 2000) and expand fiscal space (Bagattini 2011). Stabilization funds do appear to smooth government expenditure, reducing their volatility by as much as 13 percent compared to economies without such funds (Sugawara 2014).

While a stabilization fund can be a powerful fiscal tool to manage fiscal resources and create fiscal space, the establishment itself does not guarantee its success. Cross-country evidence even suggests that the effectiveness of a particular stabilization fund in shielding the domestic economy from commodity price volatility depends largely on government commitment to fiscal discipline and macroeconomic management, rather than on just the existence of the instrument itself (Gill et

\footnotetext{
${ }^{24}$ Chile's fiscal rule and its use of fiscal policy during the Great Recession illustrate an important limitation of the rule. Chile's rule specifically calls for a zero structural balance, and thus does not allow the implementation of countercyclical fiscal stimulus. The stimulus of 2009 was only implemented with a change in the rule after much deliberation by country authorities. Escape clauses in fiscal rules that accommodate such circumstances can thus provide valuable flexibility in dealing with low probability events and are included in recent fiscal rules (Schaechter et al. 2012).
} 
al. 2014). Proper designs and strong institutional environments that support their operations are crucial factors for the success of stabilization funds.

Among resource-rich economies, Norway and Chile are often treated as examples of economies with stabilization funds that are based on specific resource revenues and associated with good fiscal management (Schmidt-Hebbel 2012a, 2012b). Norway's Government Pension Fund and Chile's Economic and Social Stabilization Fund are ranked highest and third, respectively, in a scoring of 58 sovereign wealth funds and government pension funds (Bagnall and Truman 2013). The main characteristics that distinguish Norway's and Chile's funds from those with lower scores are governance and transparency and accountability of fund operations.

Medium-Term Expenditure Frameworks (MTEF). MTEFs were first introduced to facilitate modern public financial management in pursuit of long-run policy priorities in OECD economies. Among developing economies, they gained prominence in the late 1990s, as annual budgets were perceived to create uncertainty about future budgetary commitments. International financial agencies, such as the World Bank, have also sought to encourage stable allocations toward poverty reduction targets. More than two-thirds of all economies have adopted MTEFs of some form (World Bank 2013c).

The objective of MTEFs is to establish or improve credibility in the budgetary process. They seek to ensure a transparent budgetary process, where government agencies establish credible contracts for the allocation of public resources toward agreed strategic priorities, over an average of three years. The most common design of MTEFs translates macroeconomic objectives into budget aggregates and detailed spending plans; less sophisticated approaches target either aggregate fiscal goals, or micro-level costs and outcomes.

Empirical evidence suggests that credible MTEFs can significantly improve fiscal discipline (World Bank 2013c). Furthermore, the results tend to be more positive for more sophisticated frameworks (Grigoli et al. 2012). Significant heterogeneity exists, however, and certain studies limited to smaller regional samples have been unable to find conclusive evidence, possibly reflecting shortcomings in the practical implementation of MTEFs. For example, Le Houerou and Taliercio (2002) examine the design and implementation of MTEFs in a sample of African economies.

Keys to robust implementation are coordination with broader public sector reform, and sensitivity to country characteristics (World Bank 2013c). For example, Jordan's MTEF was a component of major public financial management reforms in 2004 and part of the national development strategy. The MTEF's specific objective was to improve fiscal discipline through realistic revenue projections, followed by better expenditure prioritization and the identification of fiscal space. In the case of South Africa, the MTEF was introduced in the context of high government debt and a combination of underspending by the central government and overspending by provincial governments. Underspending and overspending were both reduced following the introduction of the MTEF. One of the lessons from the experiences of South Africa, Tanzania, and Uganda is the need for realistic expectations during the preparation of the budget, without which even well-designed MTEFs cannot succeed (Holmes and Evans 2003).

\section{Conclusion}

This paper has examined whether developing economies will be able to use fiscal policy to support activity when needed. An important prerequisite for fiscal policy to be useful is that governments 
need to have the necessary fiscal space to implement countercyclical measures. Fiscal space implies a lack of binding constraints from financing requirements, such as a large pre-existing deficit, a heavy debt burden, or excessive short-term liabilities. Over the past two decades, a growing number of EM and FM have graduated from procyclical policies, towards more countercyclical policies. In large part, the earlier procyclicality had been the result of weak fiscal sustainability, which constrained policymakers' options, and political pressures to spend during times of good revenues.

Debt stocks in developing economies on average remain moderate despite being higher than expected immediately after the crisis. Fiscal deficits are substantial and have not yet returned to pre-crisis levels. Although debt has grown slowly under the current benign market conditions, especially low interest rates, the debt-to-GDP ratios could increase much more rapidly if domestic growth slows and global interest rates rise (Figure 9). This is especially relevant for some FM that have placed sovereign bonds in international markets recently and have increased their exposure to risks linked to global financing conditions. The historical experience highlights several instances in recent decades when debt ratios rose sharply (Figure 4). Private sector vulnerabilities are another source of risk that EM and FM should monitor since they have been associated with debt crises in the past. Corporate and household debt in EM and FM has risen since the crisis (Figure 10). Moreover, in some countries, rising private sector debt has been accompanied by deteriorating fiscal sustainability (World Bank 2015).

Even under the current global environment, with historically low interest rates, fiscal deficits in some developing economies seem sizeable. Under a less benign environment, with domestic growth and world interest rates at historical norms, the picture could worsen (Arteta et al. 2015). Over the medium term, in view of these risks as well as the desirability of strengthening fiscal space, developing economies will need to return their fiscal positions to more sustainable levels. For many developing economies, soft commodity prices since 2014 present an opportunity to implement subsidy reforms to help rebuild fiscal space while, at the same time, removing longstanding distortions to economic activity (Baffes et al. 2015).

The appropriate speed of adjustment towards these medium-term goals, however, depends on a range of country-specific factors, in particular the cyclical position of the economy and constraints on monetary policy. For example, it would not be appropriate to aim inflexibly at reduced deficits during years of recession. The pace at which fiscal space is restored would also depend on the degree to which monetary stimulus is constrained by concerns over financial system soundness. With restored space, fiscal policy will be more effective in providing support to activity in developing economies than under the current fiscal conditions. 


\section{References}

[1] Anderson, P. R. D., C. S. Silva, and A. Velandia-Rubiano. 2010. "Public Debt Management in Emerging Economies: Has This Time Been Different?" Policy Research Working Paper 5399, World Bank, Washington, DC.

[2] Arbatli, E., T. Baunsgaard, A. Guerson, and K-S. Min. 2010. "Fiscal Policy Response in Advanced and Emerging Economies." In Post-Crisis Fiscal Policy, ed. C. Cottarelli, P. Gerson, and A. Senhadji. Cambridge, MA: MIT Press.

[3] Arteta, C., A. Kose, F. Ohnsorge, and M. Stocker. 2015. "The Coming U.S. Interest Rate Tightening Cycle: Smooth Sailing or Stormy Waters?" Policy Research Note 2, World Bank, Washington, DC.

[4] Baffes, J., A. Kose, F. Ohnsorge, and M. Stocker. 2015. "The Great Plunge in Oil Prices: Causes, Consequences and Policy Responses." Policy Research Note 1, World Bank, Washington, DC.

[5] Bagattini, G. Y. 2011. "The Political Economy of Stabilisation Funds: Measuring Their Success in Resource-Dependent Countries." Working Paper 356, Institute of Development Studies, Brighton.

[6] Bagnall, A. E., and E. M. Truman. 2013. "Progress on Sovereign Wealth Fund Transparency and Accountability: An Updated SWF Scoreboard." Policy Brief 13-19, Peterson Institute for International Economics, Washington, DC.

[7] Blanchard, O., and R. Perotti. 2002. "An Empirical Characterization of the Dynamic Effects of Changes in Government Spending and Taxes on Output." Quarterly Journal of Economics 117 (4): 1329-68.

[8] Bornhorst, F., G. Dobrescu, G. J. Fedelino, and T. Nakata. 2011. "When and How to Adjust beyond the Business Cycle: A Guide to Structural Fiscal Balances." Technical Notes and Manuals 11/02, International Monetary Fund, Washington, DC.

[9] Bova, E., N. Carcenac, and M. Guerguil. 2014. "Fiscal Rules and the Procyclicality of Fiscal Policy in the Developing World." Working Paper 14/122, International Monetary Fund, Washington, DC.

[10] Calderon, C., and K. Schmidt-Hebbel. 2008. "Business Cycles and Fiscal Policies: the Role of Institutions and Financial Markets." Working Paper 481, Central Bank of Chile, Santiago.

[11] Debrun, X., and A. Schaechte. 2014. "Institutional Reforms and Fiscal Adjustment." In PostCrisis Fiscal Policy, ed. C. Cottarelli, P. Gerson, and A. Senhadji, 485-514. Cambridge, MA: MIT Press.

[12] Didier, T., A. Kose, F. Ohnsorge, and L. Ye. 2015. "Slowdown in Emerging Markets: Rough Patch or Prolonged Weakness?" Policy Research Note 4, World Bank, Washington, DC.

[13] Didier, T., C. Hevia, and S. L. Schmukler. 2012. "How Resilient and Countercyclical Were Emerging Economies during the Global Financial Crisis?" Journal of International Money and Finance 31 (8): 2052-77. 
[14] Eichengreen, B., and R. Hausmann. 1999. "Exchange Rates and Financial Fragility." Proceedings from the Economic Policy Symposium, Federal Reserve Bank of Kansas City, Jackson Hole, WY, August 26-28.

[15] Eskesen, L. L. 2009. "Countering the Cycle - The Effectiveness of Fiscal Policy in Korea." Working Paper 09/249, International Monetary Fund, Washington, DC.

[16] Fardoust, S., J. Y. Lin, and X. Luo. 2012. "Demystifying China's Fiscal Stimulus." Policy Research Working Paper 6221, World Bank, Washington, DC.

[17] Fasano, U. 2000. "Review of the Experience with Oil Stabilization and Savings Funds in Selected Countries." Working Paper 00/112, International Monetary Fund, Washington, DC.

[18] Frankel, J. 2011. "A Solution to Fiscal Procyclicality: The Structural Budget Institutions Pioneered by Chile." Journal Economía Chilena 14 (2): 39-78.

[19] Frankel, J. A., C. A. Végh, and G. Vuletin. 2013. "On Graduation from Fiscal Procyclicality." Journal of Development Economics 100 (1): 32-47.

[20] Gill, I. S., I. Izviorski, W. van Eeghen, and D. De Rosa. 2014. Diversified Development: Making the Most of Natural Resources in Eurasia. Washington, DC: World Bank.

[21] Grigoli, F., Z. Mills, M. Verhoeven, and R. Vlaicu. 2012. "MTEFs and Fiscal Performance: Panel Data Evidence." Policy Research Working Paper 6186, World Bank, Washington, DC.

[22] Harding, D., and A. Pagan. 2002. "Dissecting the Cycle: A Methodological Investigation." Journal of Monetary Economics 49 (2): 365-81.

[23] Hausmann, R., and U. Panizza. 2011. "Redemption or Abstinence? Original Sin, Currency Mismatches, and Counter Cyclical Policies in the New Millennium." Journal of Globalization and Development 2 (1): 1-35.

[24] Heller, P. S. 2005. "Understanding Fiscal Space." Policy Discussion Paper 05/04, International Monetary Fund, Washington, DC.

[25] Holmes, M., and A. Evans. 2003. A Review of Experience in Implementing Medium Term Expenditure Frameworks in a PRSP Context: A Synthesis of Eight Country Studies. London: Overseas Development Institute.

[26] Huidrom, R., M. A. Kose, J. Lim, and F. Ohnsorge. 2016. "Do Fiscal Multipliers Depend on Fiscal Positions?" Working Paper forthcoming.

[27] Ilzetzki, E., E. Mendoza, and C. Végh. 2013. "How Big (Small?) Are Fiscal Multipliers?" Journal of Monetary Economics 60 (2): 239-54.

[28] Ilzetzki, E. and C. Végh. 2008. "Procyclical Fiscal Policy in Developing Countries: Truth or Fiction?" NBER Working Paper 14191.

[29] IMF (International Monetary Fund). 2012. "World Economic Outlook." October, IMF, Washington, DC.

[30] . 2013. "Heavily Indebted Poor Countries (HIPC) Initiative and Multilateral Debt Relief Initiative (MDRI): Statistical Update." IMF, Washington, DC. 
[31] - 2014. "Debt Relief under the Heavily Indebted Poor Countries (HIPC) Initiatives Factsheet." IMF, Washington, DC.

[32] Jedidi, O. 2013. "Predicting Sovereign Debt Crises: A Panel Data Approach Using Composite Indices." Mimeo, University of Rennes.

[33] JP Morgan. 2014. "EMBI Global and EMBI Global Diversified: Rules and Methodology." Methodology Brief, JP Morgan.

[34] Kohler, M. 2010. "Exchange Rates during Financial Crises." BIS Quarterly Review 2010(March).

[35] M. A. Kose, S. Kurlat, and F. Ohnsorge. 2016. "A Cross-Country Database on Fiscal Space." Working Paper forthcoming.

[36] Laeven, L., and F. Valencia. 2013. "Systemic Banking Crises Database.” IMF Economic Review 2013 (61): 225-70.

[37] Le Houerou, P., and Taliercio. 2002. "Medium Term Expenditure Frameworks: From Concept to Practice, Preliminary Lessons from Africa." Africa Region Working Paper 28, World Bank, Washington, DC.

[38] Ley, E. 2009. "Fiscal Policy for Growth." PREM Note131, World Bank, Washington, DC.

[39] Ostry, J. D., A. R. Ghosh, J. I. Kim, and M. S. Qureshi. 2010. "Fiscal Space." Staff Position Note 10/11, International Monetary Fund, Washington, DC.

[40] - 2007. "Fiscal Policy in Developing Countries: A Framework and Some Questions." Policy Research Working Paper 4365, World Bank, Washington, DC.

[41] Schaechter, A., T. Kinda, N. Budina, and A. Weber. 2012. "Fiscal Rules in Response to the Crisis - Toward the "Next- Generation" Rules: A New Dataset. Working Paper 12/187, International Monetary Fund, Washington, DC.

[42] Schmidt-Hebbel, K. 2012a. "The Political Economy of Distribution and Growth in Chile." Working Paper 417, Instituto de Economía, Pontificia Universidad Católica de Chile.

[43] — 2012b. "Fiscal Institutions in Resource-Rich Economies: Lessons from Chile and Norway." Working Paper 416, Instituto de Economía, Pontificia Universidad Católica de Chile, Santiago, Chile.

[44] Snudden, S. 2013. "Countercyclical Fiscal Rules for Oil Exporting Countries." Working Paper 13/229, International Monetary Fund, Washington, DC.

[45] Sugawara, N. 2014. "From Volatility to Stability in Expenditure: Stabilization Funds in Resource-Rich Countries." Working Paper 14/43, International Monetary Fund, Washington, DC.

[46] Végh, C., and G. Vuletin. 2013. The Road to Redemption: Policy Response to Crises in Latin America. Washington, DC: International Monetary Fund.

[47] World Bank. 2013a. Global Economic Prospects June 2013: Less Volatile, but Slower Growth. Washington, DC: World Bank. 
[48] — 2013b. World Development Report 2014: Risk and Opportunity -Managing Risk for Development. Washington, DC: World Bank.

[49] . 2013c. Beyond the Annual Budget. Washington, DC: World Bank.

[50] - 2014. East Asia Economic Update October 2014: Enhancing Competitiveness in an Uncertain World. Washington, DC: World Bank.

[51] — 2015. "Having Fiscal Space and Using It. Global Economic Prospects. January 2015" Washington, DC: World Bank. 
Figure 1. Evolution of Fiscal Space

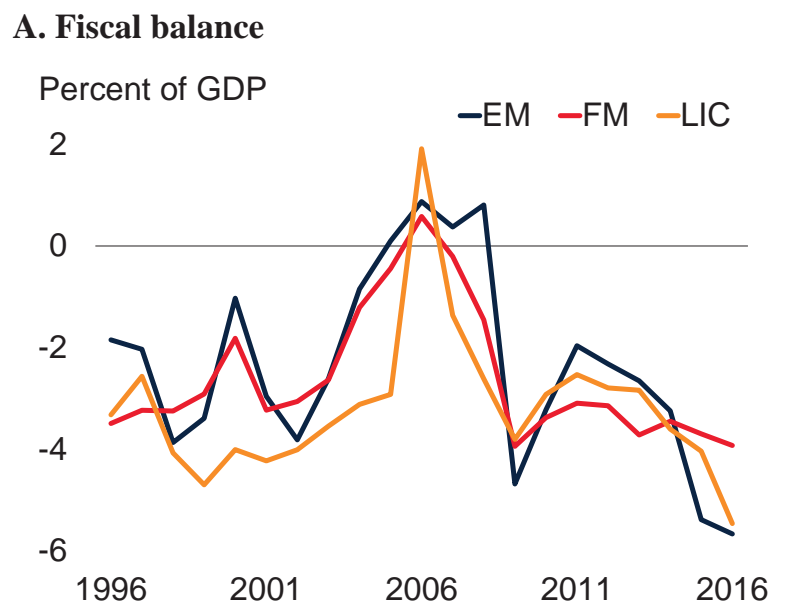

\section{B. Government debt}

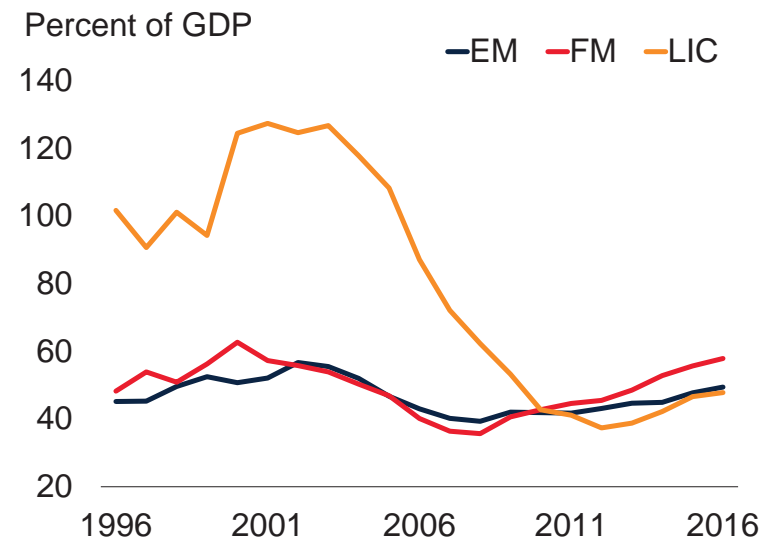

Source: World Bank estimates.

Note: All figures are based on unweighted averages across each country grouping. EM: emerging markets; FM: frontier markets; LIC: low income countries. The list of countries in each group is given in Table A1. 
Figure 2. Fiscal Space in Commodity Exporters and Importers

\section{A. Government debt}

Percent of GDP

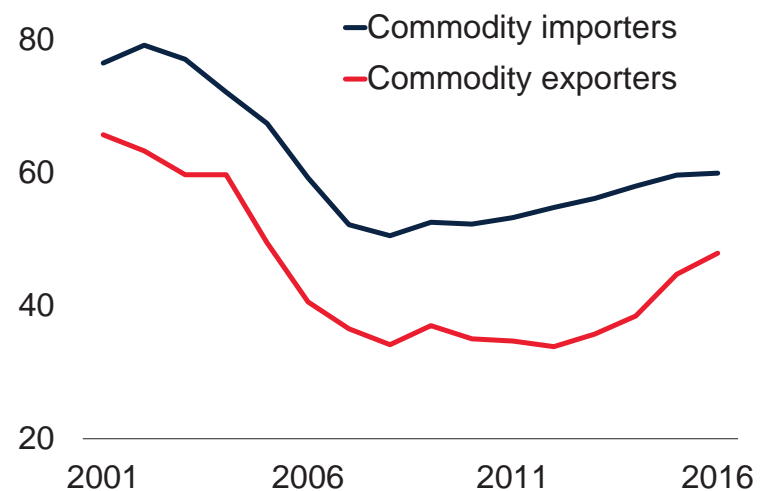

\section{B. Fiscal balance}

\section{Percent of GDP}

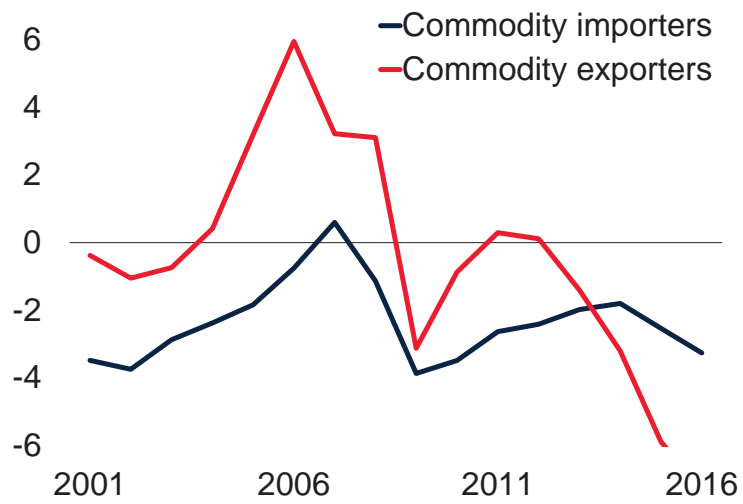

Source: World Bank estimates.

Note: Commodity exporters include all oil and mineral exporting economies that are identified as such in World Bank (2015). The list of countries classified as commodity exporters is provided in Table A2. Commodity importers are all economies that are not classified as exporters. Figures refer to unweighted averages in each country grouping. 
Figure 3. Fiscal Policy and Space during Contractions

A. Structural balance

Percent of potential GDP

-All events pre-2008 -Great Recession

0

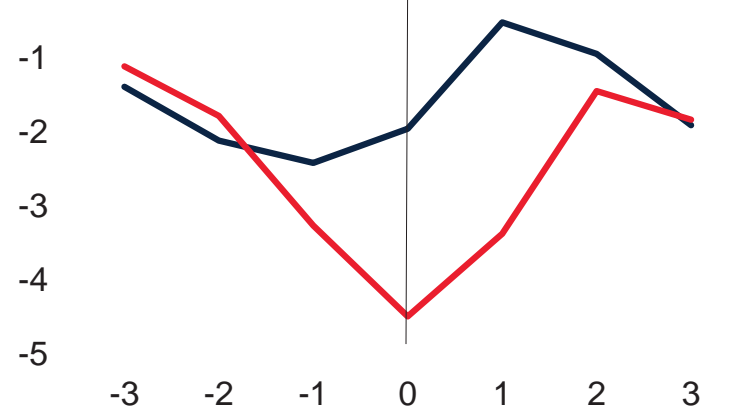

C. Exchange rate index

Index is 100 at $\mathrm{t}=0$

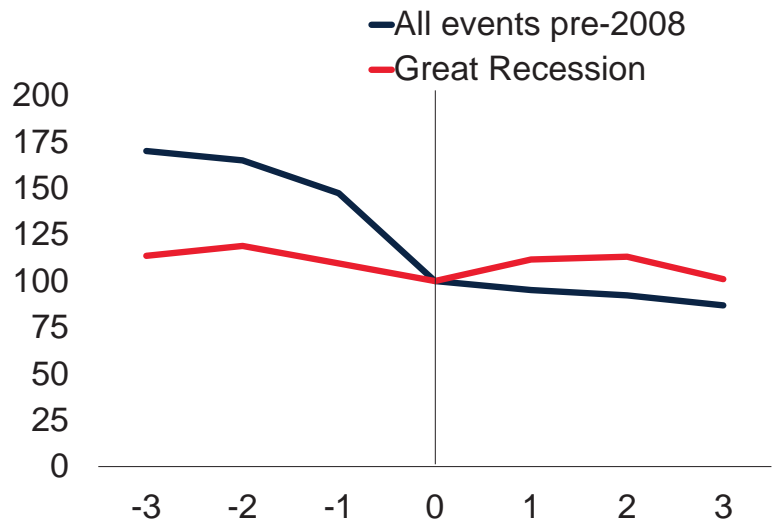

\section{B. Government debt}

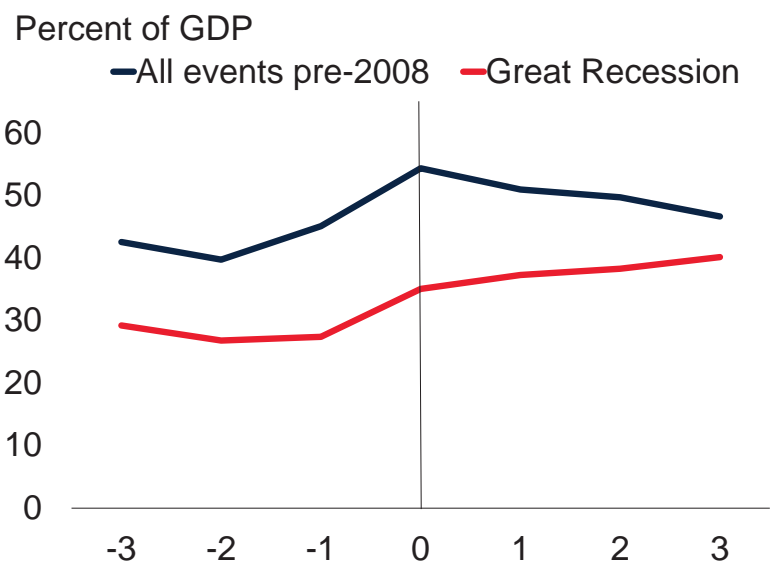

D. GDP growth

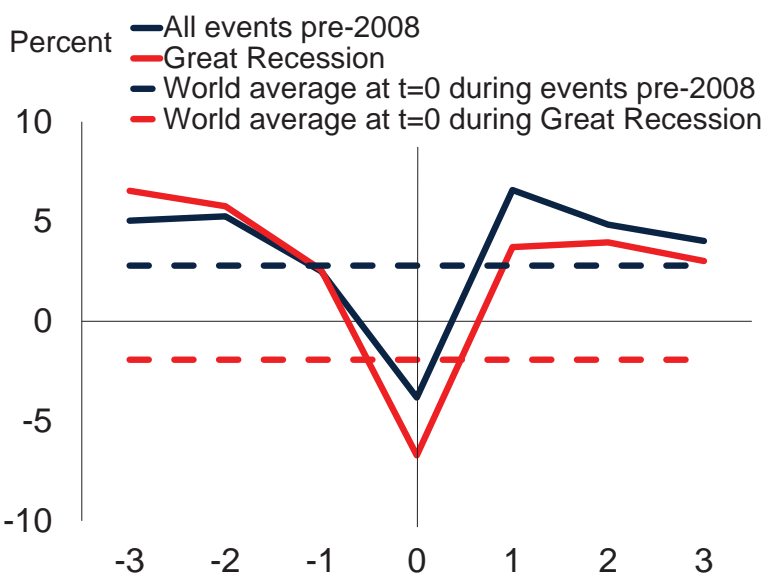

Source: World Bank estimates.

Note: ' $t=0$ ' is the year of the trough of the contraction episode. All variables refer to the unweighted sample mean. The structural balance is defined as the difference between cyclically adjusted revenues and cyclically adjusted expenditures. The exchange rate index is set to be 100 at ' $t=0$ ' and shows how exchange rates depreciated in pre-2008 contraction episodes but not during the Great Recession. The world average growth during pre-2008 contraction episodes was much higher than during the Great Recession, and so economies experiencing contractions in 2008-09 did so under more difficult global conditions than in previous contractions. The list of contraction events is provided in Table A3. 
Figure 4. Government Debt in Select Crises

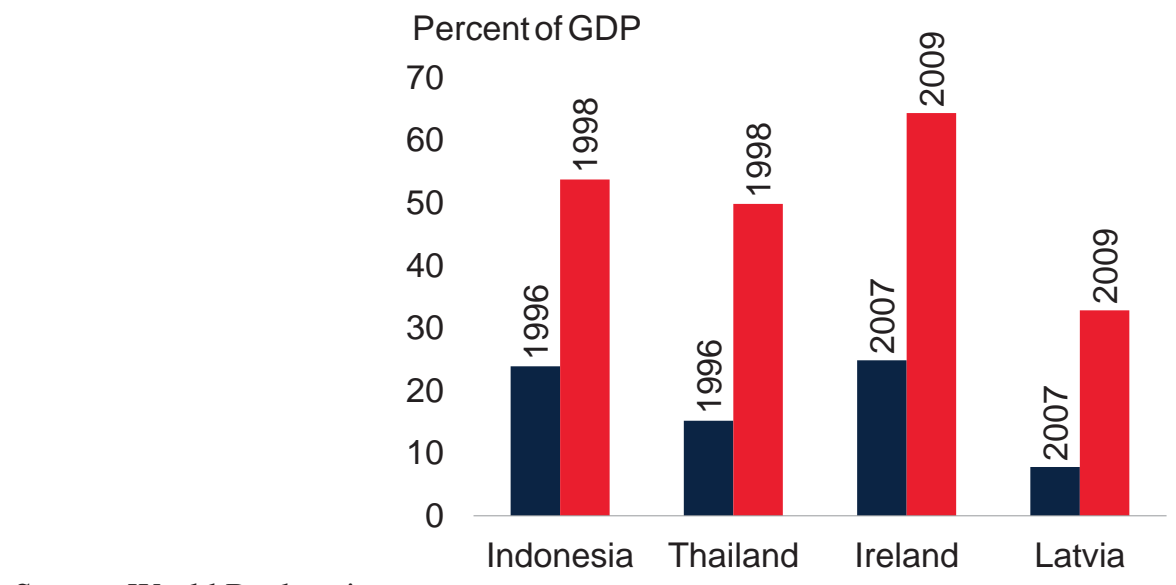

Source: World Bank estimates.

Note: Central government debt is used for Indonesia. The others refer to general government debt. 
Figure 5. Changing Stance of Fiscal Policy

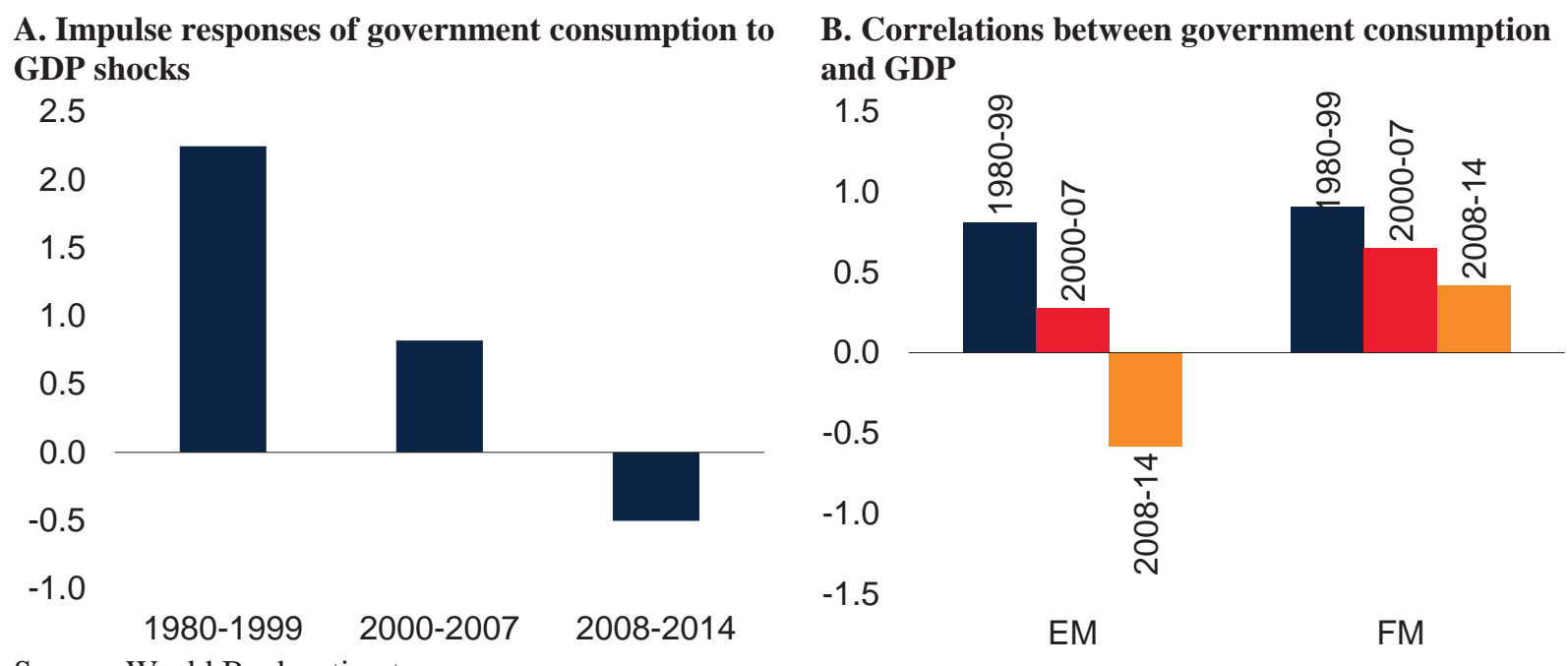

Source: World Bank estimates.

A. The cumulative impulse responses of government consumption (in percentage points) at the one-year horizon following a 1 percentage point positive shock to GDP. The impulse responses are estimated using a panel SVAR model with a sample of 15 EM and FM using quarterly data. Positive (negative) responses suggest procyclical (countercyclical) fiscal policy.

B. Correlations between the cyclical components of government consumption and GDP from an unbalanced panel of annual data for $31 \mathrm{EM}$ and $29 \mathrm{FM}$. All correlations are statistically significantly different from zero and differences in correlations across time are also statistically significant. Positive (negative) correlations suggest procyclical (countercyclical) fiscal policy. 
Figure 6. Cyclicality of Fiscal Policy and Fiscal Space

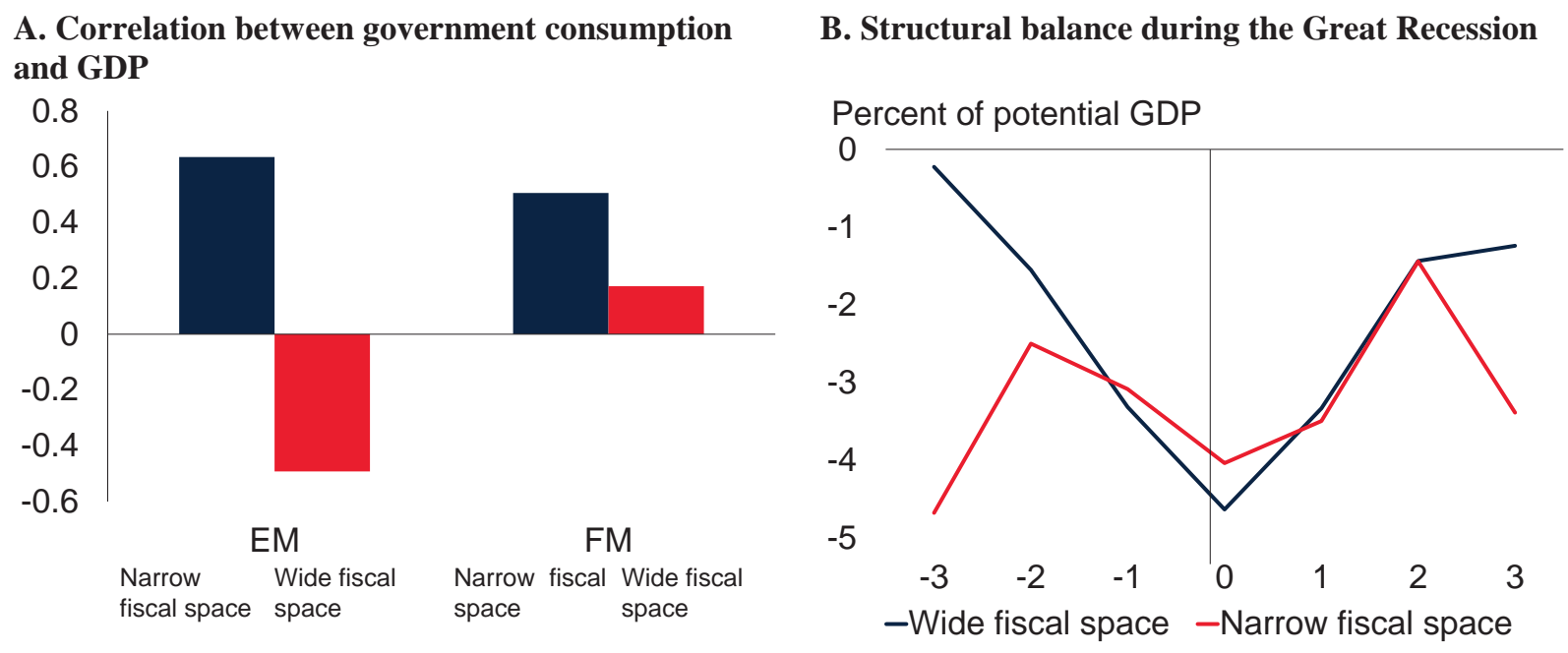

Source: World Bank estimates.

A. The correlations are between the cyclical components of government consumption and GDP with samples divided based on fiscal space from an unbalanced panel of annual data for 31 EM and 29 FM. The median debt-toGDP ratio in the full sample is 44 percent. Countries with debt-to-GDP ratios above the median are considered to have narrow fiscal space, while those with debt-to-GDP ratios below the median are considered to have wide fiscal space. All correlations are statistically significantly different from zero and across time. Positive (negative) correlations suggest procyclicality (countercyclicality).

B. ' $t=0$ ' is the year of the trough of the contraction episode. All variables refer to the unweighted sample mean. These results are based on the data sample of the event study which includes the $21 \mathrm{EM}$ and FM that experienced contractions during the Great Recession. The median debt-to-GDP ratio in the full sample of $63 \mathrm{EM}$ and FM is 44 percent. Countries with debt-to-GDP ratios above the median are considered to have narrow fiscal space, while those with debt-to-GDP ratios below the median are considered to have wide fiscal space. The list of contraction events is provided in Table A3. 
Figure 7. Fiscal Rules: Trends and Distribution

\section{A. Trends, 1952-2013}

Number of countries with balance budget rules

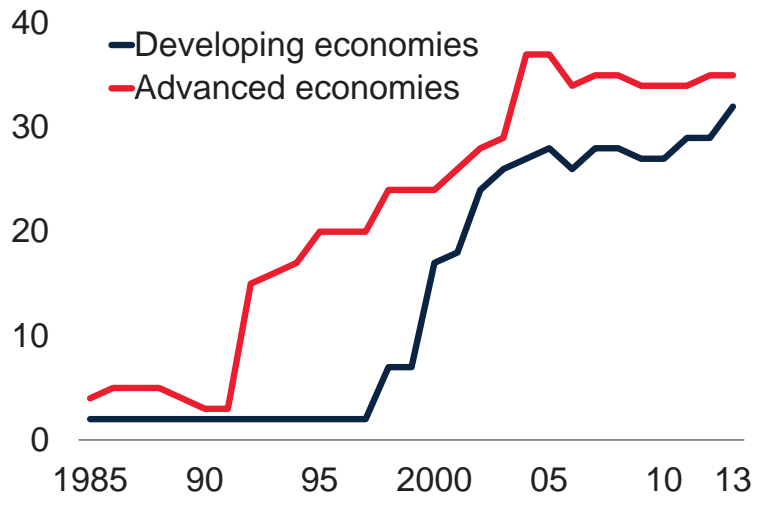

B. Distribution across developing economies, 2013

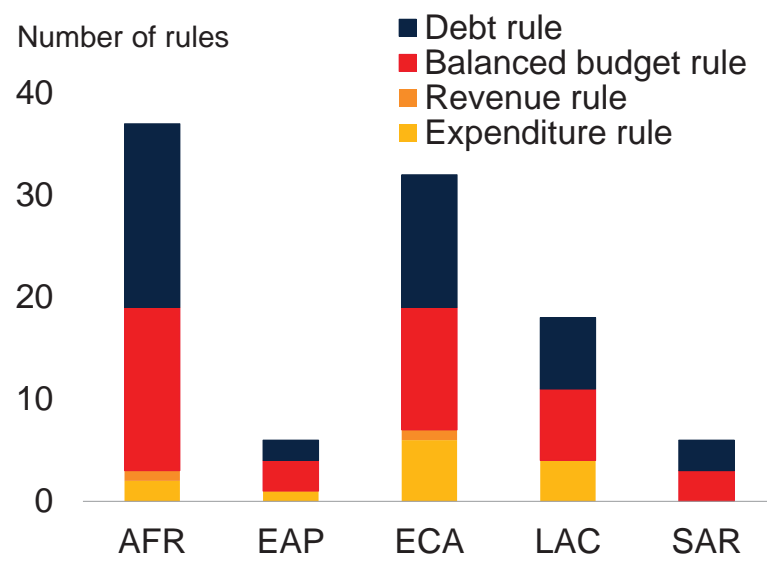

Source: World Bank estimates.

Notes: The database includes 87 economies. AFR: Sub-Saharan Africa; EAP: East Asia and Pacific; ECA: Europe and Central Asia; LAC: Latin America and Caribbean; SAR: South Asia. There is no reported fiscal rule for the Middle East and North Africa. 
Figure 8. Stabilization Funds: Trends and Distribution

\section{A. Trends, 1952-2013}

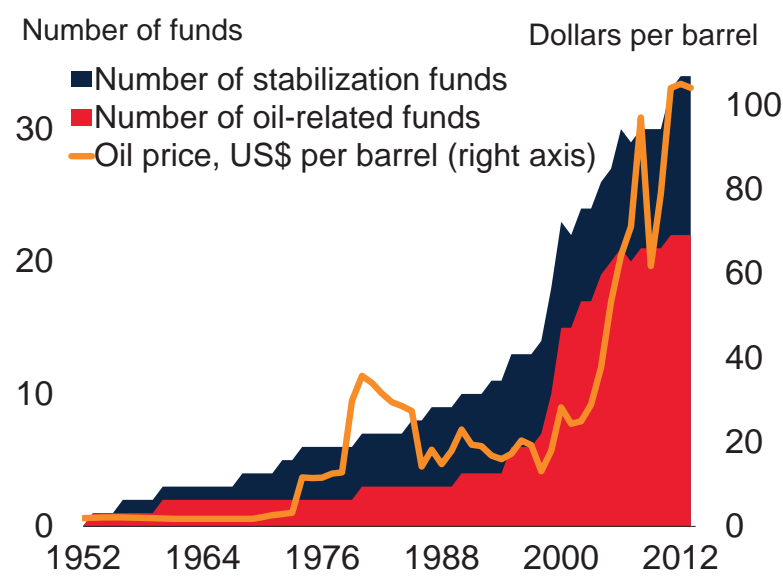

B. Distribution across developing economies, 2013

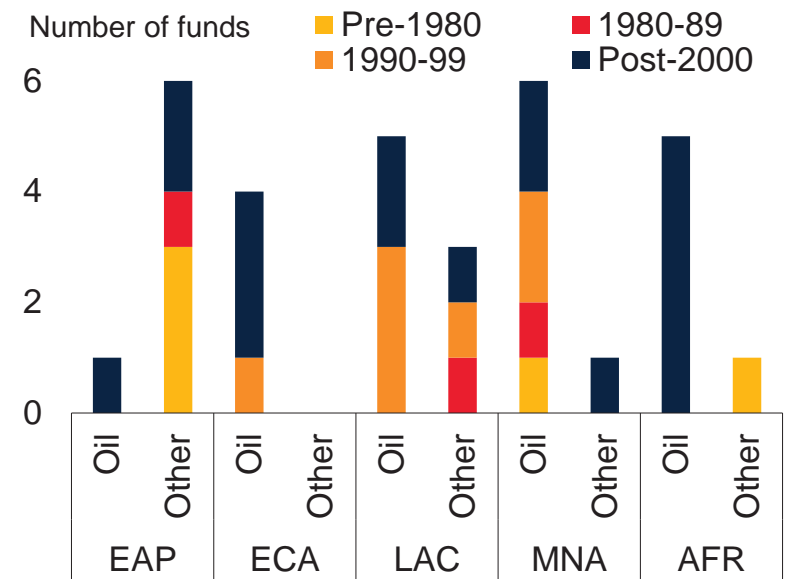

Source: World Bank estimates.

Notes: Stabilization funds here are all those listed in Sugawara (2014), together with Panama's fund (established in 2012), but excluding Norway. Oil-related stabilization funds are those whose funding sources include petroleum, the rest are referred to as "Other" in the graph. Only the first fund each country created is included if multiple funds exist (or existed) in a country. AFR: Sub-Saharan Africa; EAP: East Asia and Pacific; ECA: Europe and Central Asia; LAC: Latin America and Caribbean; MNA: Middle East and North Africa. 
Figure 9. Evolution of Financing Cost

\section{A. EM long-term interest rates}

Yield to maturity on 10-year government bond,

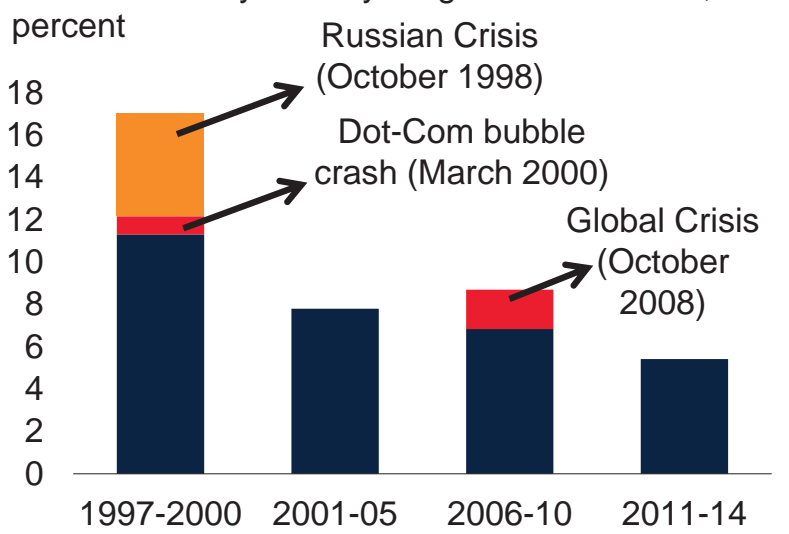

\section{B. FM long-term interest rates}

Estimated yield to maturity on 10-year government bond, percent

16

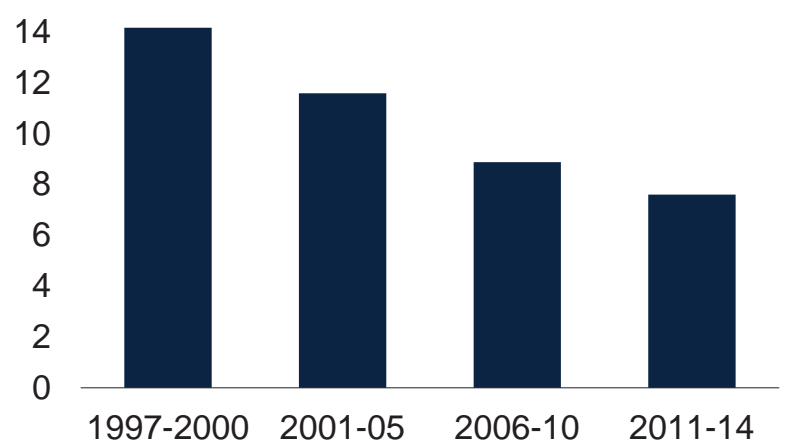

Source: World Bank estimates.

Note: All figures are based on unweighted averages across the country grouping or time period. The interest rates over a given time period are averages of daily rates. For EM, the nominal long-term interest rate is equal to the government 10-year bond yield. In the case of FM, the generic bond yield data were sparse for many economies and time periods. Hence, the nominal interest rate is estimated as the sum of 10-year U.S. Treasury yields plus the predicted spreads from a fixed-effect OLS regression of J.P. Morgan's EMBI on the Institutional Investor Rating. For the crisis periods, the interest rates refer to the average of daily rates in that month. EM: emerging markets; FM: frontier markets; LIC: low income countries. Orange and red bars indicate spikes in long-term interest rates during the relevant months. 
Figure 10. Private Sector Vulnerabilities

\section{A. Private sector credit evolution}

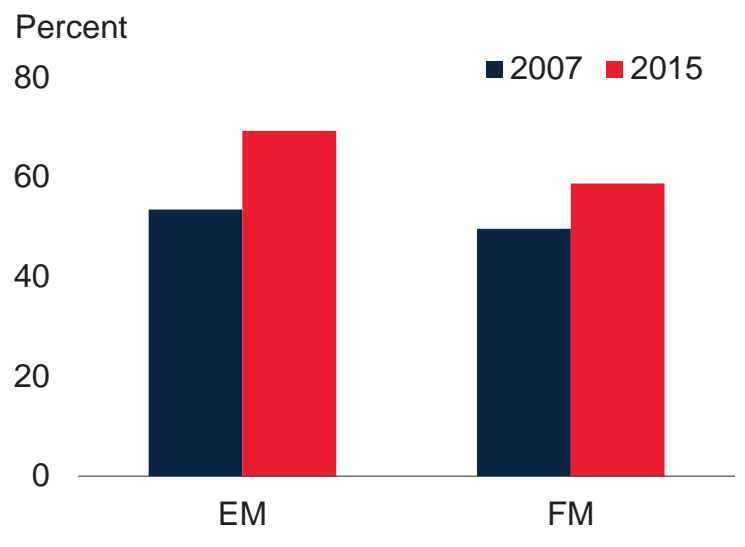

B. Credit growth and sustainability gaps in 2013

Change in private sector credit to GDP ratio 2012-13 (\%)

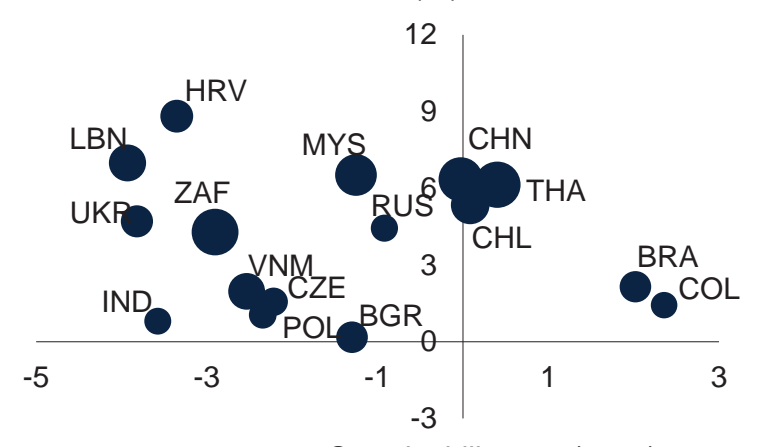

Sustainability gap (2013)

Source: World Bank estimates, World Development Indicators.

A. Domestic private sector credit as percent of GDP in emerging markets (EM) and frontier markets (FM) economies.

B. The size of the circle is proportional to domestic private credit-to-GDP ratio. The sustainability gap is the difference between the primary balance and an estimated debt-stabilizing primary balance based on interest rates and growth rates in 2013. A negative value suggests that the balance is debt increasing, a value of zero suggests that the balance holds debt constant, and positive values suggest that the balance is debt reducing. All economies in the figure are EMEs and FMEs with domestic private credit-to-GDP ratios greater than 50 percent. 


\section{List of Tables in the Supplementary Appendix}

Table A1: Country Classification

Table A2: List of Commodity Exporters

Table A3: Contraction Events in Emerging and Frontier Markets

Table A4: Data Sources and Variables

Table A5: Descriptive Statistics of Fiscal Space and Policy Measures

Table A6: Contraction Events between 1990 and 2007 excluded because of Data Constraints 


\section{Appendix}

Challenges of Fiscal Policy in Emerging and Developing Economies Raju Huidrom, M. Ayhan Kose, and Franziska L. Ohnsorge 
Table A1: Country Classification

\begin{tabular}{|c|c|c|c|}
\hline AM & EM & FM & LIC \\
\hline Australia & Argentina* & Bangladesh & Afghanistan \\
\hline Austria & Bahrain & Bolivia & Benin \\
\hline Belgium & Brazil* & Botswana & Burkina Faso \\
\hline Canada & Chile* & Bulgaria* & Burundi \\
\hline Denmark & China & Cote d'Ivoire & Cambodia \\
\hline Finland & Colombia* & Croatia* & Central African Republic \\
\hline Franc & Czech Republic* & Cyprus & Chad \\
\hline Germany & Egypt, Arab Rep. & Ecuador & Comoros \\
\hline Greece & Hungary* & Estonia & Congo, Dem. Rep. \\
\hline Hong Kong SAR, China & India & Ghana & Eritrea \\
\hline Ireland & Indonesia & Honduras & Ethiopia \\
\hline Italy & Israel* & Jamaica & Gambia, The \\
\hline Japan & Jordan & Kenya & Guinea \\
\hline Netherlands & Korea, Rep. & Latvia & Guinea-Bissau \\
\hline New Zealand & Malaysia & Lebanon & Haiti \\
\hline Norway & Mexico* & Macedonia, FYR & Liberia \\
\hline Portugal & Morocco & Mauritius & Madagascar \\
\hline Singapore & Nigeria & Mongolia & Malawi \\
\hline Spain & Oman & Namibia & Mali \\
\hline Sweden & Pakistan & Qatar & Mozambique \\
\hline Switzerland & Peru & Romania* & Myanmar \\
\hline United Kingdom & Philippines & Rwanda & Nepal \\
\hline \multirow[t]{11}{*}{ United States } & Poland* & Senegal & Niger \\
\hline & Russian Federation & Serbia & Sierra Leone \\
\hline & Saudi Arabia & Slovenia & Somalia \\
\hline & Slovak Republic* & Trinidad and Tobago & South Sudan \\
\hline & South Africa* & Tunisia & Tajikistan \\
\hline & Sri Lanka & Ukraine & Tanzania \\
\hline & Thailand & Vietnam & Togo \\
\hline & Turkey* & Zambia & Uganda \\
\hline & United Arab Emirates & & \\
\hline & Venezuela, RB & & \\
\hline & Zimbabwe & & \\
\hline
\end{tabular}

Note: Table shows the list of countries in each country grouping used in the paper. Economies with an asterisk are the ones included in the estimation of the SVAR model. 
Table A2: List of Commodity Exporters

\begin{tabular}{ll}
\hline & Commodity \\
\hline Albania & Libya \\
Algeria & Malaysia \\
Angola & Mauritania \\
Argentina & Mexico \\
Armenia & Mongolia \\
Australia & Mozambique \\
Azerbaijan & Namibia \\
Bahrain & Niger \\
Bolivia & Nigeria \\
Bosnia and Herzegovina & Norway \\
Botswana & Oman \\
Brazil & Papua New Guinea \\
Bulgaria & Peru \\
Cameroon & Russian Federation \\
Canada & Rwanda \\
Central African Republic & Saudi Arabia \\
Chad & South Africa \\
Chile & South Sudan \\
Colombia & Sudan \\
Congo, Dem. Rep. & Syrian Arab Republic \\
Congo, Rep. & Tanzania \\
Cote d'Ivoire & Togo \\
Denmark & Trinidad and Tobago \\
Ecuador & Turkmenistan \\
Gabon & United Arab Emirates \\
Georgia & United Kingdom \\
Guinea & Uzbekistan \\
Indonesia & Venezuela, RB \\
Iran, Islamic Rep. & Vietnam \\
Iraq & Yemen, Rep. \\
Jamaica & \\
Kazakhstan & Zumbia \\
\hline & \\
\hline
\end{tabular}

Note: Table shows the list of commodity exporters used in the paper. The classification follows World Bank (2015). 
Table A3: Contraction Events in Emerging and Frontier Markets

\begin{tabular}{lccc}
\hline A. Between $\mathbf{1 9 9 0}$ and $\mathbf{2 0 0 7}$ & & & \\
\hline Country & Year & Country Group & Real GDP Growth (\%) \\
\hline Argentina & 2002 & EM & -10.9 \\
Bahrain & 1994 & EM & -0.3 \\
Chile & 1999 & EM & -0.8 \\
Côte d'Ivoire & 2000 & FM & -3.7 \\
Colombia & 1999 & EM & -4.2 \\
Korea, Rep. & 1998 & EM & -5.7 \\
Sri Lanka & 2001 & EM & -1.5 \\
Morocco & 1993 & EM & -1 \\
Malaysia & 1998 & EM & -7.4 \\
Oman & 1999 & EM & -0.1 \\
Philippines & 1998 & EM & -0.6 \\
Mexico & 1995 & EM & -5.8 \\
\hline B. Between 2008 and 2009 & & & \\
\hline Bulgaria & 2009 & FM & -5.5 \\
Botswana & 2009 & FM & -7.8 \\
Chile & 2009 & EM & -1 \\
Cyprus & 2009 & FM & -1.7 \\
Czech Republic & 2009 & EM & -4.5 \\
Estonia & 2009 & FM & -14.1 \\
Honduras & 2009 & FM & -2.4 \\
Hungary & 2009 & EM & -6.8 \\
Latvia & 2009 & FM & -18 \\
Mexico & 2009 & EM & -4.7 \\
Malaysia & 2009 & EM & -1.5 \\
Romania & 2009 & FM & -6.8 \\
Russian Federation & 2009 & EM & -7.8 \\
Slovak Republic & 2009 & EM & -4.9 \\
Slovenia & 2009 & FM & -8 \\
Thailand & 2009 & EM & -2.3 \\
Trinidad and Tobago & 2009 & FM & -4.4 \\
Turkey & 2009 & EM & -4.8 \\
Ukraine & 2009 & FM & -14.8 \\
South Africa & 2009 & EM & -1.5 \\
Zimbabwe & 2008 & & -17.7 \\
\hline
\end{tabular}

Note: Table shows the contraction events in emerging markets (EM) and frontier markets (FM). An economy is considered here to have experienced a contraction event if its growth in a given year fulfills two conditions. The first is that the growth is negative (i.e., a contraction), and the second is that the growth is more than one standard deviation below the average that the country experienced in the 1990-2013 period. 
Table A4: Data Sources and Variables

\begin{tabular}{lc}
\hline \multicolumn{1}{c}{ Source } & Variables \\
\hline GDP (constant 2005 USD) & WDI, WBG \\
GDP (current USD); & WDI, WBG \\
GDP (current LCU); & WDI, WBG \\
Government consumption (constant 2005 USD) & WDI, WBG \\
Private household consumption (constant 2005 USD) & WDI, WBG \\
Domestic credit to the private sector (as share of GDP) & WDI, WBG \\
Gross capital formation (constant 2005 USD) & WDI, WBG \\
Gross government debt as a share of GDP & WEO, IMF \\
Exchange rate index (1995=100) & IFS, IMF \\
Brent crude oil price per barrel (2010 USD) & GEM Commodities Database, WBG \\
\hline
\end{tabular}

Note: Table shows the data sources of the variables used in the paper. 
Table A5: Descriptive Statistics of Fiscal Space and Policy Measures

\begin{tabular}{|c|c|c|c|}
\hline \multirow{2}{*}{ Variable } & \multicolumn{3}{|c|}{ Quartile } \\
\hline & 0.25 & 0.5 & 0.75 \\
\hline \multicolumn{4}{|l|}{ Government debt (percent of GDP) } \\
\hline $\mathrm{AM}$ & 42 & 59 & 84 \\
\hline EM, FM, OD & 25 & 43 & 68 \\
\hline LICs & 35 & 56 & 106 \\
\hline Primary balance (percent of GDP) & -2.5 & -0.3 & 2.1 \\
\hline Structural balance (percent of potential GDP) & -4.4 & -2.2 & 0 \\
\hline Overall fiscal balance (percent of potential GDP) & -4.6 & -2.3 & 0.2 \\
\hline \multicolumn{4}{|l|}{ Government debt (percent of revenues) } \\
\hline $\mathrm{AM}$ & 91 & 137 & 208 \\
\hline EM, FM, OD & 87 & 163 & 259 \\
\hline LICs & 203 & 331 & 575 \\
\hline Overall deficit (percent of revenue) & -17.8 & -8.2 & 0.6 \\
\hline Sustainability gap (overall balance) & -3.5 & 1 & 5.7 \\
\hline Sustainability gap (primary balance) & -3.6 & -1 & 1.5 \\
\hline $\begin{array}{l}\text { Sustainability gap under current conditions (primary } \\
\text { balance) }\end{array}$ & -3.6 & -0.6 & 2.2 \\
\hline \multicolumn{4}{|l|}{ Total external debt/GDP (\%) } \\
\hline $\mathrm{AM}$ & 117 & 183 & 282 \\
\hline EM, FM, OD & 28 & 45 & 73 \\
\hline LICs & 34 & 66 & 98 \\
\hline \multicolumn{4}{|l|}{ External private debt/GDP (\%) } \\
\hline $\mathrm{AM}$ & 76 & 132 & 244 \\
\hline EM, FM, OD & 0 & 1 & 6 \\
\hline LICs & 0 & 0 & 0.1 \\
\hline \multicolumn{4}{|l|}{ Domestic credit to private Sector/GDP (\%) } \\
\hline $\mathrm{AM}$ & 84 & 106 & 148 \\
\hline EM, FM, OD & 17 & 30 & 51 \\
\hline LICs & 6 & 11 & 17 \\
\hline \multicolumn{4}{|l|}{ Short-term external debt/ Total external debt (\%) } \\
\hline $\mathrm{AM}$ & 31 & 39 & 58 \\
\hline EM, FM, OD & 5 & 12 & 20 \\
\hline LICs & 2 & 5 & 10 \\
\hline \multicolumn{4}{|l|}{ Short-term external debt/reserves (\%) } \\
\hline $\mathrm{AM}$ & 527 & 1029 & 2349 \\
\hline EM, FM, OD & 11 & 37 & 87 \\
\hline LICs & 12 & 32 & 88 \\
\hline Total external debt/reserves (\%) & 212 & 421 & 1261 \\
\hline Total external debt/reserves (without gold) (\%) & 216 & 440 & 1397 \\
\hline
\end{tabular}

Note: Table shows the descriptive statistics of fiscal space and policy measures during 1980-2013. All figures are unweighted. 
Table A6: Contraction Events between 1990 and 2007 excluded because of Data Constraints

\begin{tabular}{lccc}
\hline Country & Year & Country Group & Real GDP Growth (\%) \\
\hline Bulgaria & 1992 & FM & -7.3 \\
Bulgaria & 1996 & FM & -9.0 \\
Brazil & 1990 & EM & -4.3 \\
Czech Republic & 1991 & EM & -11.6 \\
Ecuador & 1999 & FM & -4.7 \\
Estonia & 1994 & FM & -1.6 \\
Honduras & 1994 & FM & -1.3 \\
Honduras & 1999 & FM & -1.9 \\
Hungary & 1992 & EM & -3.1 \\
Indonesia & 1998 & EM & -13.1 \\
Israel & 2002 & EM & -0.6 \\
Kenya & 1992 & FM & -0.8 \\
Latvia & 1992 & FM & -32.1 \\
Macedonia, FYR & 1993 & FM & -7.5 \\
Macedonia, FYR & 2001 & FM & -4.5 \\
Mongolia & 1993 & FM & -3.2 \\
Mongolia & 2009 & FM & -1.3 \\
Peru & 1990 & EM & -5.1 \\
Philippines & 1991 & EM & -0.6 \\
Poland & 1991 & EM & -7.0 \\
Romania & 1992 & FM & -8.8 \\
Romania & 1998 & FM & -4.8 \\
Russian Federation & 1994 & EM & -12.6 \\
Rwanda & 1994 & FM & -50.2 \\
Senegal & 1990 & FM & -0.7 \\
Senegal & 1994 & FM & 0.0 \\
Serbia & 1993 & FM & -30.5 \\
Serbia & 19992 & -11.2 \\
Slovak Republic & 1993 & FM & -3.7 \\
Slovenia & 1992 & EM & -5.5 \\
Thailand & 1998 & FM & -10.5 \\
Turkey & 1994 & EM & -4.7 \\
Turkey & 2001 & EM & -5.7 \\
Venezuela, RB & 2003 & -7.8 \\
South Africa & 1992 & -2.1 \\
Zambia & EM & -1.7 \\
Zambia & EM & -17.9 \\
Zimbabwe & 1992 & \\
Zimbabwe & & & \\
\hline
\end{tabular}

Note: Table shows the contraction events in emerging markets (EM) and frontier markets (FM). An economy is considered here to have experienced a contraction event if its growth in a given year fulfills two conditions. The first is that the growth is negative (i.e., a contraction), and the second is that the growth is more than one standard deviation below the average that the country experienced in the 1990-2013 period. 